\title{
Improving Livelihoods through Watershed Interventions: A Case Study of SABMiller India Project
}

\author{
Rajesh Nune, ${ }^{*}$ Ch. Srinivasa Rao, R. Sudi, Suhas P. Wani, \\ Kaushal K. Garg and D.S. Prasad Rao \\ International Crops Research Institute for the Semi-Arid Tropics, \\ Patancheru, India
}

\begin{abstract}
Water plays an important role in the semi-arid tropical region to address water scarcity, land degradation, and crop and livestock productivity which improves the rural livelihood system. The Charminar Breweries (formerly SABMiller, and since merged with AB InBev) in Sangareddy district, Telangana, India has adopted an integrated approach to address the above issues in nearby villages of the plant under corporate social responsibility initiative between 2009 and 2017 in a phased manner. The major interventions implemented in the project focused on rainwater harvesting, productivity enhancement through soil test-based fertilizer application, improved crop cultivars, enriching soil organic carbon and improved agronomic practices. Further, livestock productivity was addressed by promoting spent malt (a by-product of the brewing industry, rich in carbohydrate, protein and other minerals) and improved breeding through artificial insemination. Various $e x$-situ interventions for water management enabled harvesting of nearly $150,000 \mathrm{~m}^{3}$ water every year and facilitated groundwater recharge, which resulted in increased water table of $0.5-1 \mathrm{ft}$ across the geographical extent of nearly 7000 ha. Further, productivity interventions enhanced crop yield and cropping intensity by $30-50 \%$ compared to baseline situation. The livestock interventions enhanced milk yield by 1-2 1/day/animal. The watershed programme also introduced various income-generating activities for women and landless such as distribution of spent malt as animal feed, kitchen garden, vermicomposting and nursery raising. The programme has benefited nearly $\mathbf{5 0 0 0}$ households directly or indirectly and increased household income by ₹ 10,000 to ₹25,000 per annum and contributed significantly towards improving rural livelihood along with strengthening various environmental services.
\end{abstract}

\subsection{Introduction}

Management of water resources has an important role in semi-arid regions, not only for increasing agricultural productivity and improving the livelihoods of the poor, but also for sustainable development of many water-based industries. The looming water scarcity as well as the projected increasing water demand by competing sectors like agriculture, environment and industry demonstrates that users are bound to put more pressure on the scarce and finite water resources. As there is a direct link between increasing agricultural productivity and economic

^ Corresponding author: r.nune@cgiar.org 
development for poverty reduction, it is evident that $1 \%$ increase in agricultural yields translates to $0.6-1.2 \%$ decrease in the number of absolute poor (Thirtle et al., 2002; World Bank, 2005).

\subsubsection{The initiative}

The Charminar Breweries (formerly SABMiller, and since merged with $A B$ InBev) is located on the bank of river Manjira, a perennial tributary of river Godavari, in the Sangareddy district of Telangana, India (Fig. 5.1). The Manjira river water is one of the major water resources. The farmers located near the river Manjira divert the river water to their fields for irrigation, especially during dry and rabi (post-rainy) seasons. It is critical to ensure that the surrounding communities do not view the factory as an exploiter of the water resources and for this necessary care needs to be taken to ensure sustainable development and management of the limited water resource in the surrounding areas. Under these circumstances, SABMiller and the International Crops Research Institute for the Semi-Arid Tropics (ICRISAT), Patancheru decided to adopt an integrated water resource management approach at catchment scale as a key to address water sustainability and management in the surrounding villages of Charminar Breweries for improving rural livelihoods as a win-win strategy.

\subsubsection{Goal and objectives}

The overall goal and objective of SABMiller initiative is to develop sustainable water resources in the surrounding areas of the factory while contributing to improving the livelihoods of the people dependent on agriculture. The specific objectives of the project are as follows.

(i) To improve water availability and agricultural productivity in selected villages through rainwater conservation, harvesting, its efficient use, and productivity enhancement measures for improving livelihoods.

(ii) To build capacity of the farmers in the selected villages to develop sustainable water management practices and enhance groundwater availability and use efficiency.

\subsection{ICRISAT-SABMiller India Project}

\subsubsection{Background of the study area}

The ICRISAT-SABMiller India Project has taken up integrated watershed management programme in a geographical area of around 7665 ha, spread across ten villages, located just 10-15 km away from Sangareddy town of Sangareddy district in Telangana state as shown in Fig. 5.1. The study area falls in one of the semi-arid tropical regions in the state, which is a hot spot for poverty, hunger, malnutrition, food insecurity, water scarcity and degraded land resources. This project was started in 2009 in four villages, namely Fasalvadi (Sangareddy mandal), Venkatakistapur, Shivampet and Chakriyal (Pulkal mandal). In 2013, the project expanded to three other villages, namely Sultanpur, Korpole and Vendikol (Pulkal mandal), and then in 2014, additional three villages, namely Chowtakur, Bommareddygudem and Upparigudem (Pulkal mandal) were added to the project. The project villages had a total population of 30,738 and 5754 households (Table 5.1). The average annual rainfall in the project area is around $895 \mathrm{~mm}$. The villages are characterized by undulated topography with an average slope of $2.5 \%$. Soil in these villages is dominated by Vertisol (black cotton soil) with medium to high water-holding capacity.

Of the total geographical area of the project villages, $90-92 \%$ of area is under agricultural use and the remaining area is under wasteland and non-agricultural use in the villages. Of the total agricultural area, $73 \%$ of area is rainfed and $23 \%$ of area is under irrigation condition (Table 5.2). The farmers grow cotton and maize predominantly in rainfed areas, and paddy and sugarcane in irrigated areas of these villages.

\subsubsection{Identification of constraints}

During rapid rural appraisal assessment done by the team of ICRISAT scientists in the selected villages, the following constraints were identified.

- The soils were low in fertility because of imbalanced use of inputs of plant nutrients 


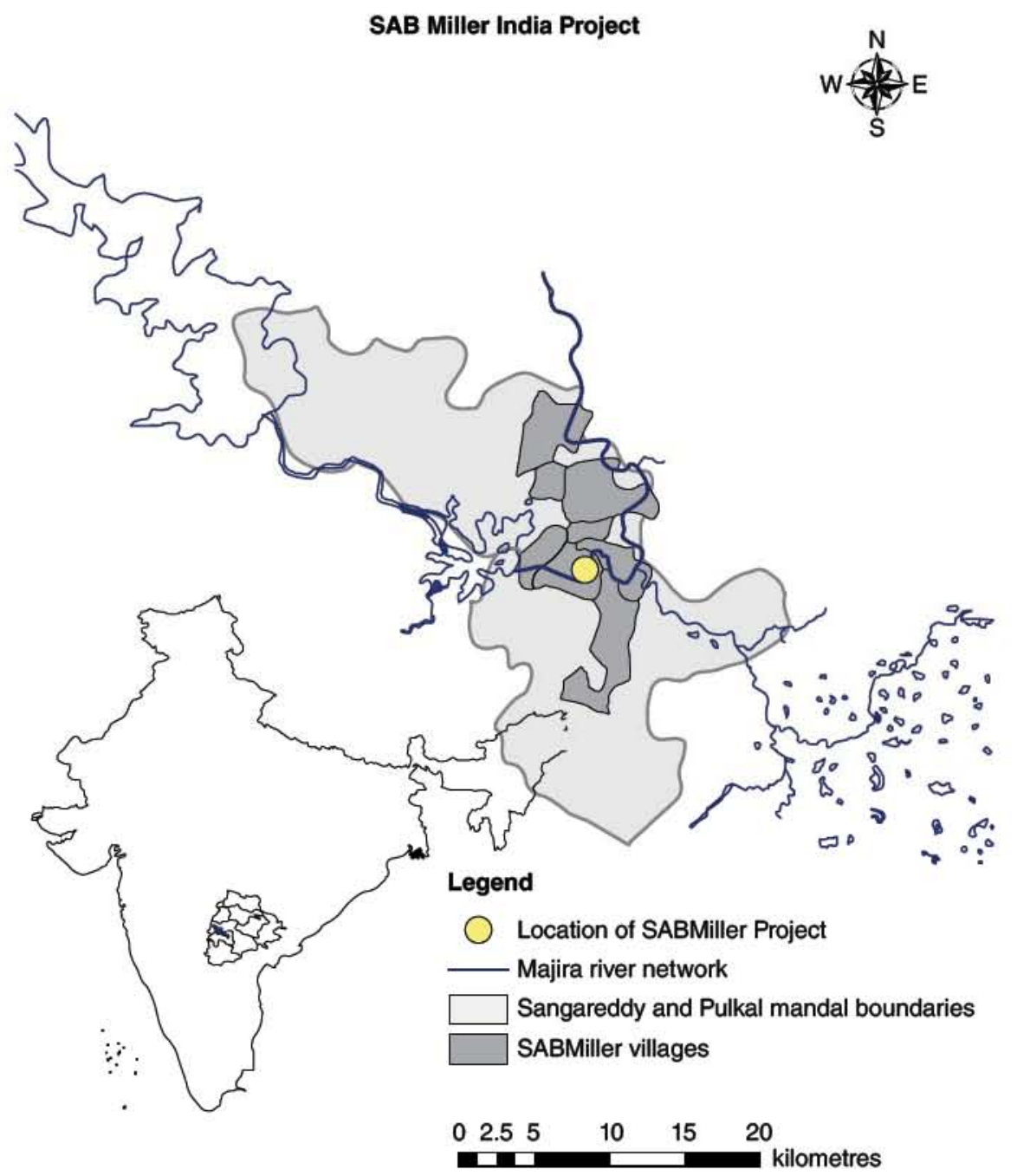

Fig. 5.1. Location map of SABMiller India Project villages.

through external sources and very low addition of organic matter.

- Inappropriate land and water management systems and insufficient water harvesting structures have led to a decrease in groundwater levels with time.

- There was hardly any evidence of efforts being made for water conservation, harvesting, storage and recharge of groundwater.

- The storage capacities of traditional water harvesting structures used by the community for domestic and cattle uses were reduced by siltation and poor maintenance.
- Besides water scarcity, fields were deficient in secondary and micronutrients like sulfur, zinc and boron in addition to organic carbon, nitrogen and phosphorus.

\subsection{The Process}

\subsubsection{Strategy}

- Use integrated genetic and natural resource management approach to bring about 
Table 5.1. Demographic details of the project villages.

\begin{tabular}{lccccc}
\hline Village & $\begin{array}{c}\text { Households } \\
\text { (no.) }\end{array}$ & $\begin{array}{c}\text { Population } \\
\text { (no.) }\end{array}$ & $\begin{array}{c}\text { Livestock } \\
\text { (no.) }\end{array}$ & $\begin{array}{c}\text { Milch animals } \\
\text { (no.) }\end{array}$ & $\begin{array}{c}\text { Year of } \\
\text { project start }\end{array}$ \\
\hline Fasalvadi & 1,050 & 5,360 & 850 & 190 & 2009 \\
Shivampet & 841 & 4,220 & 1,050 & 210 & 2009 \\
Venkatakistapur & 275 & 1,160 & 410 & 70 & 2009 \\
Chakriyal & 360 & 2,200 & 1,010 & 255 & 2009 \\
Korpole & 816 & 4,159 & 680 & 68 & 2013 \\
Sultanpur & 384 & 2,980 & 320 & 32 & 2013 \\
Vendikol & 372 & 1,420 & 146 & 15 & 2013 \\
Chowtakur & 1,020 & 6,890 & 380 & 38 & 2014 \\
Upparigudem & 326 & 1,259 & 140 & 14 & 2014 \\
Bommareddygudem & 310 & 1,090 & 162 & 16 & 2014 \\
Total & 5,754 & 30,738 & 5,148 & 908 & - \\
\hline
\end{tabular}

Table 5.2. Land use in the project villages.

\begin{tabular}{lccccc}
\hline Village & $\begin{array}{c}\text { Rainfed area } \\
\text { (ha) }\end{array}$ & $\begin{array}{c}\text { Irrigated } \\
\text { area (ha) }\end{array}$ & $\begin{array}{c}\text { Wasteland } \\
\text { (ha) }\end{array}$ & $\begin{array}{c}\text { Nonagricultural } \\
\text { land (ha) }\end{array}$ & $\begin{array}{c}\text { Total watershed } \\
\text { area (ha) }\end{array}$ \\
\hline Fasalvadi & 716 & 247 & 292 & 57 & 1312 \\
Shivampet & 853 & 170 & 14 & 8 & 1045 \\
Venkatakistapur & 237 & 59 & 2 & 0 & 298 \\
Chakriyal & 74 & 559 & 25 & 0 & 658 \\
Korpole & 1100 & 368 & 0 & 52 & 1520 \\
Sultanpur & 844 & 95 & 0 & 21 & 960 \\
Vendikol & 272.6 & 72 & 0 & 15 & 360 \\
Chowtakur & 793 & 164 & 0 & 35 & 992 \\
Upparigudem & 174 & 76 & 4 & 18 & 272 \\
Bommareddygudem & 143 & 78 & 8 & 15 & 244 \\
Total & 5207 & 1888 & 345 & 221 & 7661 \\
\hline
\end{tabular}

sustainable management of water and enhance livelihoods within the watershed.

- Consortium approach to implement holistic and integrated development of watershed.

- Knowledge-based entry point for building rapport with the communities.

- Nothing is made available free for experimentation or evaluation except knowledge. Farmers need to pay for material support and the project would provide a small incentive. Farmers contribute $60 \%$ of the cost for the inputs to test improved technologies.

- Demand-driven interventions rather than supply-driven provision of technologies and products.

- Ensure involvement of small and marginal farmers as well as women for enhancing their incomes.
- Enhance rainwater conservation, improve water use efficiency and manage the water demand while improving the livelihoods.

- Farmers' participatory research for development and inclusive market-oriented development approach.

- Microenterprises as income-generating activities for enhancing incomes of the community members.

\subsubsection{Partner consortia}

- District Water Management Agency, Sangareddy, Government of Telangana

- Watershed committee and village organizations 
- BAIF Development Research Foundation BIRD (BAIF Institute for Rural Development)

- SABMiller India

- Rural Education \& Agriculture Development (READ), a non-governmental organization (NGO)

- ICRISAT

\subsubsection{Community mobilization and formation of watershed committee}

Watershed committee of SABMiller India villages was formed to implement the watershed work along with READ, the selected NGO. Farmers are the primary stakeholders and beneficiaries. Hence, involvement of community was important for successful execution of project activity/interventions and to ensure longterm sustainability of the project. Women and Scheduled Caste/Scheduled Tribe candidates and members from the panchayat were also involved in the formation of watershed committee, as per common guidelines (GoI, 2011).
The committee was constituted in an open meeting and the objectives were briefed clearly. The committee members and villagers along with NGO staff were involved in each and every stage of project planning and execution of proposed interventions.

\subsubsection{Entry-point activity: soil test}

Soil testing as a knowledge-based entry point built strong trust between farmers, NGO and agency, and helped in effective planning and implementation of watershed activities. Farmers were trained to collect soil samples from their villages for analysing soil nutrient status using stratified random soil sampling method and samples were analysed in state-of-the-art laboratory at ICRISAT (Sahrawat et al., 2008). Soil test results showed that large numbers of farmers' fields (50-80\%) were deficient in organic carbon and also in secondary and micronutrients such as zinc, sulfur and boron (Table 5.3). The total number of soil samples collected from the first 4

Table 5.3. Nutrient analysis of soil samples collected from farmers' fields in project villages.

\begin{tabular}{|c|c|c|c|c|c|c|c|c|c|}
\hline \multirow[b]{2}{*}{ Village } & \multirow[b]{2}{*}{ Indicator } & \multirow[b]{2}{*}{$\mathrm{pH}$} & \multirow{2}{*}{$\begin{array}{c}E C \\
(\mathrm{dS} / \mathrm{m})\end{array}$} & \multirow{2}{*}{$\begin{array}{c}\text { Organic } \\
\text { C (\%) }\end{array}$} & \multirow{2}{*}{$\begin{array}{l}\text { Olsen P } \\
(\mathrm{mg} / \mathrm{kg})\end{array}$} & \multirow{2}{*}{$\begin{array}{l}\text { Exch. } \mathrm{K}^{\mathrm{a}} \\
(\mathrm{mg} / \mathrm{kg})\end{array}$} & \multicolumn{3}{|c|}{$\begin{array}{l}\text { Extractable nutrient } \\
\text { elements }(\mathrm{mg} / \mathrm{kg})\end{array}$} \\
\hline & & & & & & & S & B & $\mathrm{Zn}$ \\
\hline \multirow[t]{2}{*}{ Fasalvadi } & Mean & 7.4 & 0.6 & 0.43 & 18 & 187 & 39.1 & 0.36 & 0.8 \\
\hline & $\%$ fields deficient & & & 75 & 35 & 0 & 50 & 80 & 55 \\
\hline \multirow[t]{2}{*}{ Venkatakistapur } & Mean & 7.8 & 0.5 & 0.49 & 13.2 & 163 & 48.5 & 0.47 & 0.62 \\
\hline & $\%$ fields deficient & & & 67 & 20 & 0 & 27 & 73 & 80 \\
\hline \multirow[t]{2}{*}{ Shivampet } & Mean & 7.8 & 0.2 & 0.38 & 10.5 & 199 & 10.2 & 0.49 & 0.53 \\
\hline & $\%$ fields deficient & & & 83 & 26 & 0 & 74 & 70 & 83 \\
\hline \multirow[t]{2}{*}{ Chakriyal } & Mean & 7.9 & 0.6 & 0.52 & 21.2 & 130 & 62.1 & 0.89 & 0.69 \\
\hline & $\%$ fields deficient & & & 47 & 5 & 5 & 26 & 26 & 63 \\
\hline \multirow[t]{2}{*}{ Sultanpur } & Mean & 7.8 & 0.18 & 0.45 & 10.5 & 151 & 9.5 & 1.99 & 0.69 \\
\hline & $\%$ fields deficient & & & 70 & 25 & 5 & 55 & 30 & 70 \\
\hline \multirow[t]{2}{*}{ Korpole } & Mean & 7.9 & 0.36 & 0.44 & 14.9 & 216 & 27.5 & 1.13 & 1.31 \\
\hline & $\%$ fields deficient & & & 70 & 35 & 5 & 48 & 30 & 35 \\
\hline \multirow[t]{2}{*}{ Vendikol } & Mean & 7.9 & 0.14 & 0.33 & 7.8 & 263 & 15.1 & 1.06 & 0.8 \\
\hline & $\%$ fields deficient & & & 100 & 40 & 0 & 90 & 35 & 80 \\
\hline \multirow[t]{2}{*}{ Bommareddygudem } & Mean & 7.5 & 0.18 & 0.53 & 7.7 & 118 & 17 & 0.57 & 1.15 \\
\hline & $\%$ fields deficient & & & 50 & 50 & 20 & 45 & 45 & 50 \\
\hline \multirow[t]{2}{*}{ Upparigudem } & Mean & 7.9 & 0.16 & 0.42 & 7.7 & 79 & 11.5 & 0.55 & 0.7 \\
\hline & $\%$ fields deficient & & & 65 & 45 & 25 & 70 & 60 & 85 \\
\hline \multirow[t]{2}{*}{ Chowtakur } & Mean & 7.6 & 0.17 & 0.42 & 14.6 & 198 & 21.9 & 0.88 & 0.59 \\
\hline & $\%$ fields deficient & & & 70 & 8 & 5 & 55 & 35 & 70 \\
\hline
\end{tabular}

${ }^{\mathrm{a} E x c h} . \mathrm{K}=$ exchangeable potassium 
villages selected in 2009, 3 villages selected in 2013 and 3 villages selected in 2014 were 77 , 80 and 89 respectively.

\subsubsection{Awareness and capacity building}

Several awareness programmes and regular interactions were conducted with the farming community on various project interventions and agricultural practices. The community was exposed to ICRISAT campus, Patancheru and Adarsha watershed, Kothapally to develop awareness of improved method of cultivation, best agricultural practices, soil and water conservation interventions, crop demonstration trials, etc. Nearly 3340 farmers participated in various training programmes, field exposure visits and field days during 2009-16 (Table 5.4).

\subsection{Interventions}

\subsubsection{Productivity enhancement through application of soil test-based fertilizers}

Based on soil test results, crop specific nutrient recommendations were provided to all the farmers in the villages. More importantly, use of micronutrients for different cereal (paddy, maize, etc.) and cash crops (sugarcane and cotton) were promoted. A number of farmers' participatory demonstration trials were undertaken in kharif (rainy) and rabi seasons since the project inception. Figure 5.2 shows the amount of micronutrients supplied under the farmers' demonstration trials during the seven-year period. Nearly $31,400 \mathrm{~kg}$ of gypsum, $9740 \mathrm{~kg}$ of zinc sulphate and $708 \mathrm{~kg}$ of agribor were made available in pilot villages during the project period. The total area covered so far in all the villages with micronutrient usage is nearly 5430 acres (Table 5.5). The usage of micronutrients such as zinc sulphate and agribor in each of the villages was more or less same (1391 kg of zinc sulphate and $101 \mathrm{~kg}$ of agribor). The usage of micronutrients for paddy, sugarcane and cotton was more than other crops in the villages (Table 5.5).

\subsubsection{Enhancing water resources availability}

With the technical support of ICRISAT staff, potential locations for soil and water conservation structures were identified by the watershed committee, NGO and villagers. Several water harvesting structures such as check-dams, gully control structures, farm ponds, percolation tanks, mini-percolation tanks, sunken ponds, well recharge pits, water absorption trenches, etc. were constructed (Fig. 5.3). About 94,000 $\mathrm{m}^{3}$ water storage capacity was developed in the pilot villages during 2010-16 with different soil and water harvesting structures. The major waterharvesting structures created $\left(84,800 \mathrm{~m}^{3}\right)$ in these villages vary in storage capacities based on the size of the structure and purpose. The average storage capacities of these structures are $50 \mathrm{~m}^{3}$ for loose boulders; $150 \mathrm{~m}^{3}$ for sunken ponds; $100 \mathrm{~m}^{3}$ for rock-fill dams; $150 \mathrm{~m}^{3}$ for gabion structures; $350 \mathrm{~m}^{3}$ for mini-percolation tanks; $3500-5500 \mathrm{~m}^{3}$ for percolation tanks; $850 \mathrm{~m}^{3}$ for open well recharge structures; and $3000-12,000 \mathrm{~m}^{3}$ for check-dams. A total number of 347 structures have been created by the ICRISAT-SABMiller India Project in the pilot villages since 2010 (Table 5.6).

The total coverage area of all ten villages in this project is hydrologically divided into two small watersheds as shown in Fig. 5.4. The first watershed (Watershed 2009) covers around

Table 5.4. Awareness and capacity-building programmes conducted during the project period.

\begin{tabular}{|c|c|c|c|c|c|c|c|c|c|}
\hline Particulars & 2009 & 2010 & 2011 & 2012 & 2013 & 2014 & 2015 & 2016 & Total \\
\hline No. of training programmes & 3 & 2 & 3 & 3 & 4 & 3 & 4 & 6 & 28 \\
\hline $\begin{array}{l}\text { Exposure visits (ICRISAT } \\
\text { and Kothapally) }\end{array}$ & - & 2 & - & - & 2 & 3 & 2 & 1 & 10 \\
\hline Field days & - & 1 & - & - & 1 & - & - & - & 2 \\
\hline No. of participants/trainees & 200 & 350 & 450 & 460 & 430 & 660 & 390 & 396 & 3336 \\
\hline
\end{tabular}




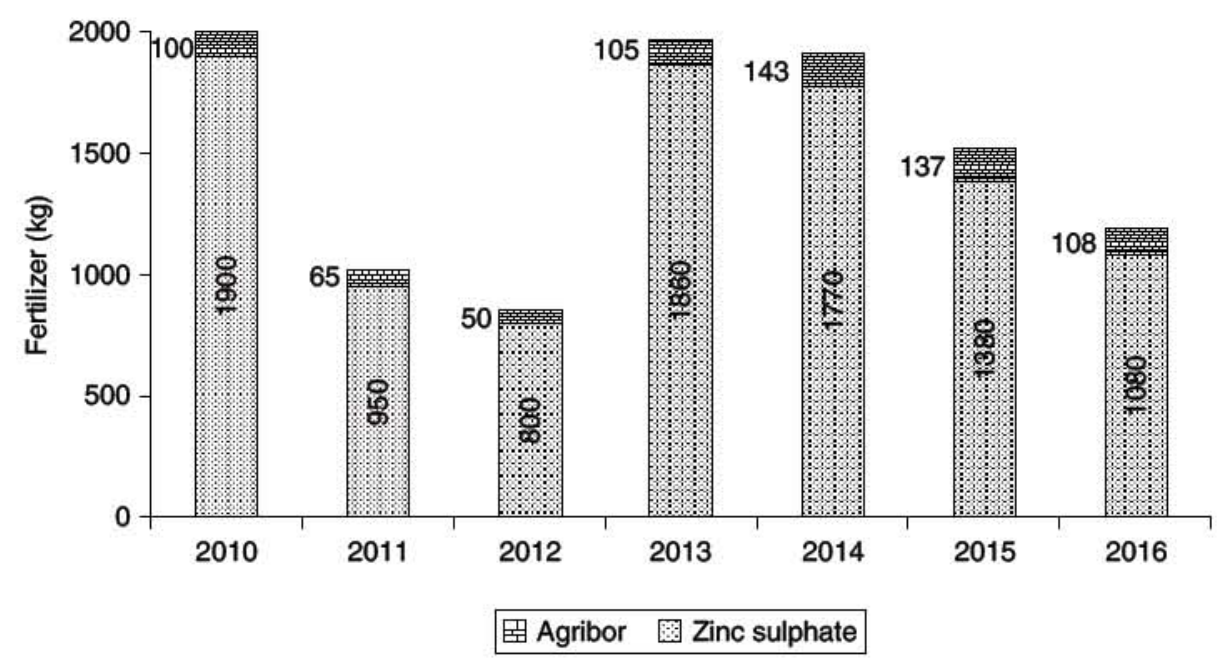

Fig. 5.2. Micronutrient usage from 2010 to 2016 in project villages.

Table 5.5. Crop area (acres) with application of micronutrients in SABMiller India pilot villages since project inception.

\begin{tabular}{lcrrrrrrr}
\hline Village & Cotton & Maize & Pigeonpea & Sorghum & Paddy & Sugarcane & Others & Total \\
\hline Fasalvadi & 180 & 59 & 25 & 58 & 344 & 378 & 50 & 1094 \\
Shivampet & 138 & 26 & 18 & 19 & 303 & 297 & 28 & 829 \\
Venkatakistapur & 124 & 45 & 15 & 11 & 86 & 62 & 10 & 353 \\
Chakriyal & 20 & 6 & 8 & 2 & 223 & 296 & 25 & 580 \\
Vendikol & 98 & 13 & 27 & 11 & 172 & 127 & 16 & 464 \\
Sultanpur & 87 & 22 & 38 & 12 & 104 & 63 & 32 & 358 \\
Korpole & 154 & 28 & 32 & 8 & 195 & 150 & 15 & 582 \\
Upparigudem & 14 & 9 & 22 & 12 & 100 & 48 & 4 & 209 \\
Bommareddygudem & 6 & 4 & 14 & 0 & 55 & 14 & 0 & 93 \\
Chowtakur & 88 & 12 & 31 & 0 & 373 & 314 & 50 & 868 \\
Total & 909 & 224 & 230 & 133 & 1955 & 1749 & 230 & 5430 \\
\hline
\end{tabular}

3420 ha with four villages (Fasalvadi, Shivampet, Venkatakistapur and Chakriyal) and the second watershed (Watershed 2013-14) covers 6560 ha with six villages (Vendikol, Sultanpur, Korpole, Upparigudem, Bommareddygudem and Chowtakur) in Pulkal mandal. The stream-flow of Watershed 2009 flows towards south and joins Manjira river at downstream of Manjira reservoir, whereas the stream-flow of Watershed 2013-14 flows towards north and joins Manjira river at downstream of Watershed 2009 as shown in Fig. 5.5. The total hydrological coverage area of the two watersheds is 9980 ha. The total capacity of major water-harvesting structures created in all ten villages is $84,800 \mathrm{~m}^{3}$, in which $47,700 \mathrm{~m}^{3}$ has been created in Watershed 2009 and $37,100 \mathrm{~m}^{3}$ has been created in Watershed 2013-14 as given in Tables 5.7 and 5.8.

\subsubsection{Agroforestry and tree plantation}

Agroforestry was promoted by planting trees on farm bunds, common lands and wasteland and was strengthened with community participation and also with the help of various government schemes in the project villages. Nearly 53,000 trees of different species were planted during the project period (Table 5.9). Moreover, 14,000 plants were cultivated under horticulture promotion in pilot villages. 


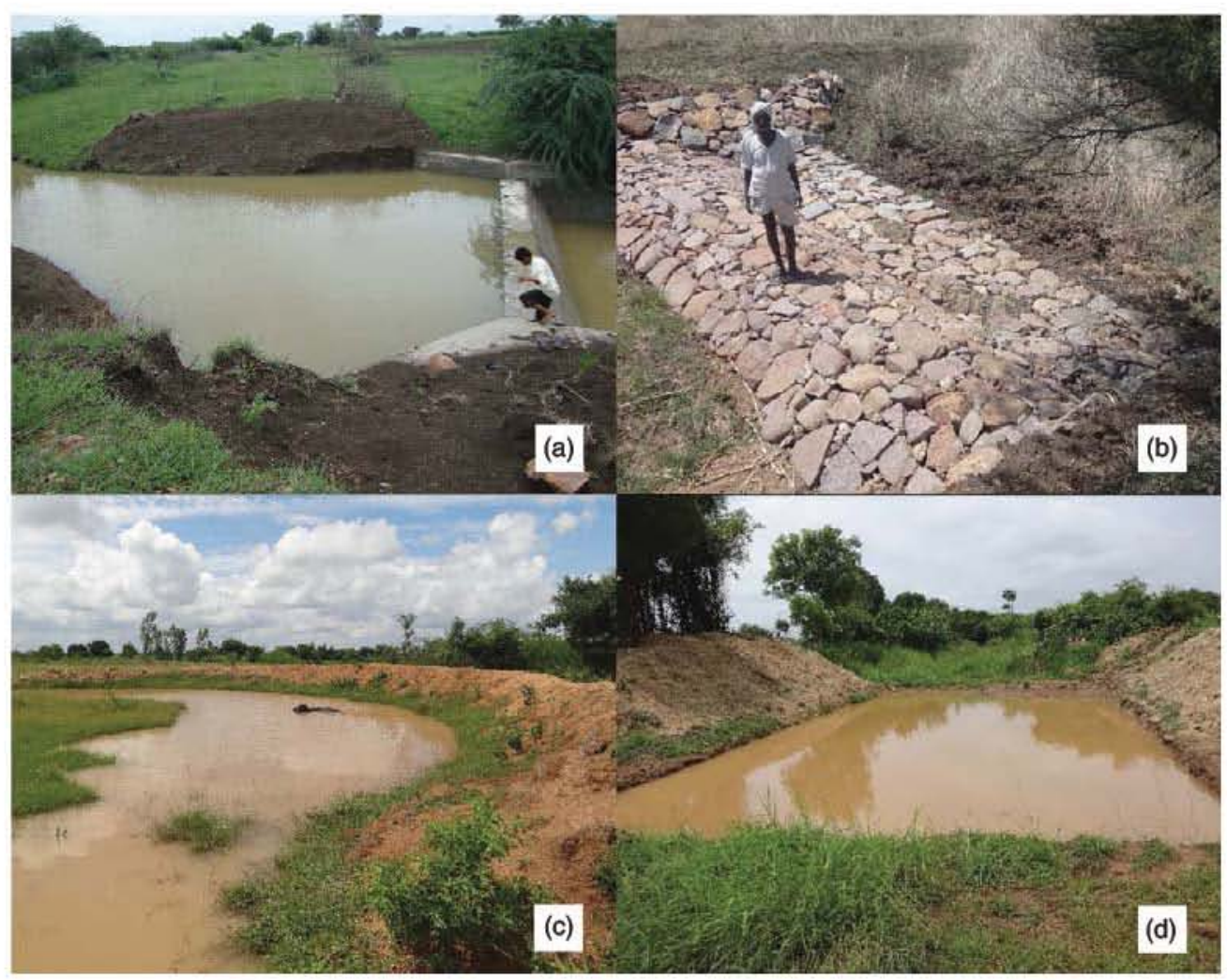

Fig. 5.3. Water-harvesting structures constructed in project villages: (a) check-dam in Shivampet; (b) rock-fill dam in Fasalvadi; (c) percolation tank in Chowtakur; (d) sunken pond in Sultanpur.

Table 5.6. Water harvesting structures (no.) constructed in the pilot villages during 2010-16.

\begin{tabular}{lcccccccr}
\hline Village & 2010 & 2011 & 2012 & 2013 & 2014 & 2015 & 2016 & Total \\
\hline Fasalvadi & 18 & 26 & 6 & 9 & & & & 59 \\
Shivampet & 34 & 56 & 4 & 14 & 2 & & & 110 \\
Venkatakistapur & & 7 & & & 22 & & & 29 \\
Vendikol & & & & 1 & 9 & 19 & & 29 \\
Korpole & & & & & 29 & 4 & 4 & 37 \\
Sultanpur & & & & & 30 & 6 & & 36 \\
Upparigudem & & & & & & 2 & 10 & 12 \\
Chowtakur & 52 & 89 & 10 & 24 & 92 & 66 & 14 & 347 \\
Total & & & & & & & &
\end{tabular}

\subsection{Investments and Incremental Benefits}

\subsubsection{Productivity enhancement through soil test-based fertilizer application}

Crop yields in the project villages increased with application of balanced and micronutrient fertilizers (Table 5.10). On average (2010-16), the response (increase in yield) to the application of balanced and micronutrient fertilizers of rainfed crops especially pulses such as chickpea and pigeonpea ( $27 \%$ to $28 \%$ ) was more than irrigated crops such as sugarcane, paddy, maize and cotton $(11 \%$ to $19 \%)$. The average cost of micronutrients applied in the improved practice was ₹2350 per ha. The farmer gained net income 


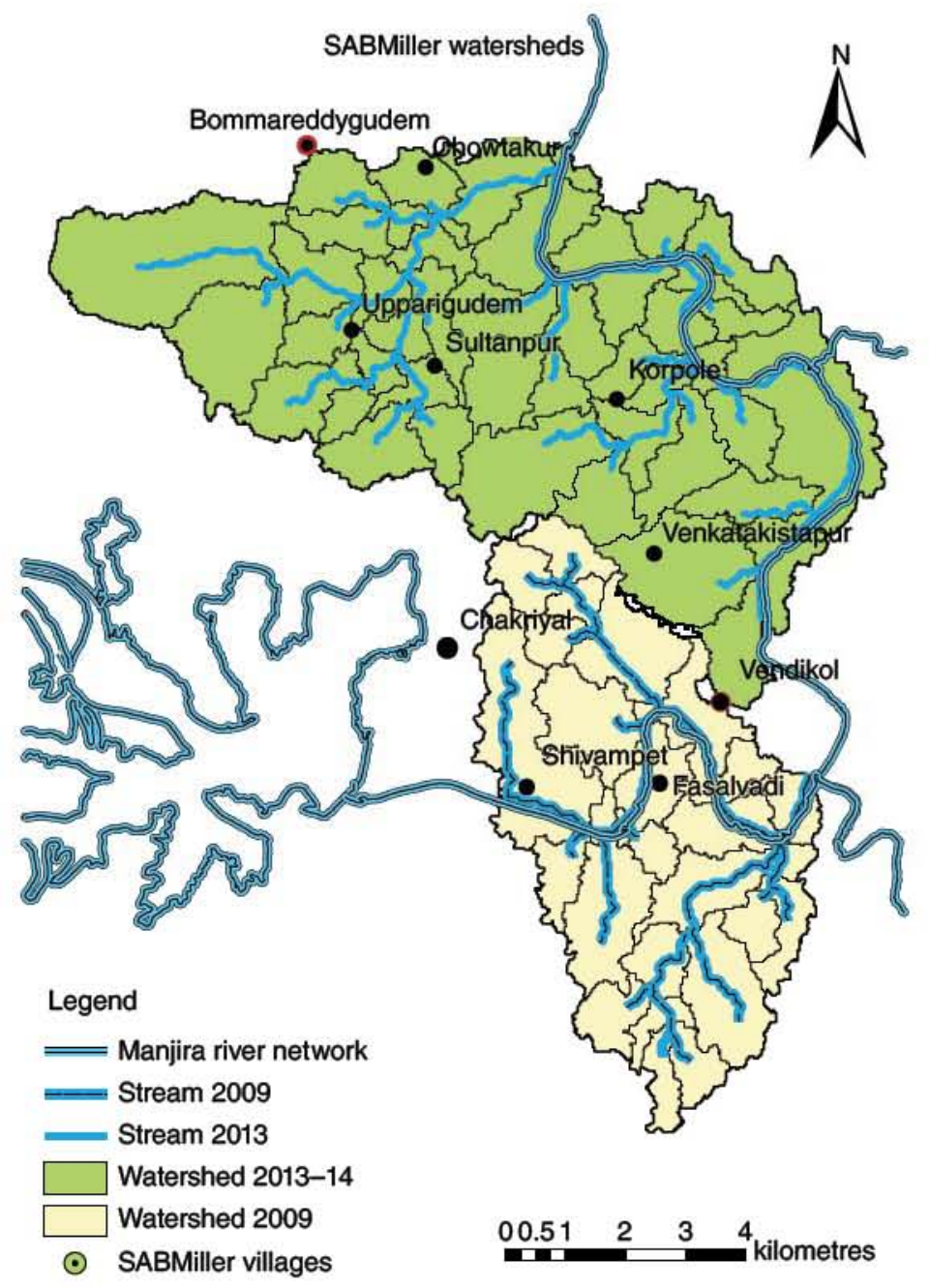

Fig. 5.4. Location map of SABMiller India Project watersheds started in 2009 and 2013-14.

of ₹13,500 and ₹11,800 per ha for chickpea and pigeonpea respectively in addition to the gain followed by farmers' practice (Table 5.11). Application of small quantity of micronutrients has significantly benefited in increasing crop yields and consequently farmers' income (Srinivasa Rao et al., 2014).

\subsubsection{Enhancing water resource availability}

The daily rainfall data that occurred in Sangareddy mandal was collected and analysed. The average annual rainfall in both the watersheds was $895 \mathrm{~mm}$. The rainfall from 2010 to 2016 was separated and normal, wet and dry years were indicated based on the annual rainfall. If annual rainfall is less than $671 \mathrm{~mm}(<0.75$ times average annual rainfall) that year is considered as dry, if annual rainfall is more than $1118 \mathrm{~mm}$ (>1.25 times average annual rainfall) that year is considered as wet and if annual rainfall is $671-1118 \mathrm{~mm}$ that year is considered as normal. As per annual rainfall and observations made by field staff in the villages, the average number of water fillings in the water-harvesting structures was noted down for few years during the project implementation and the same was assumed for all the years. The effective recharge made in the villages was considered as $80 \%$ of 


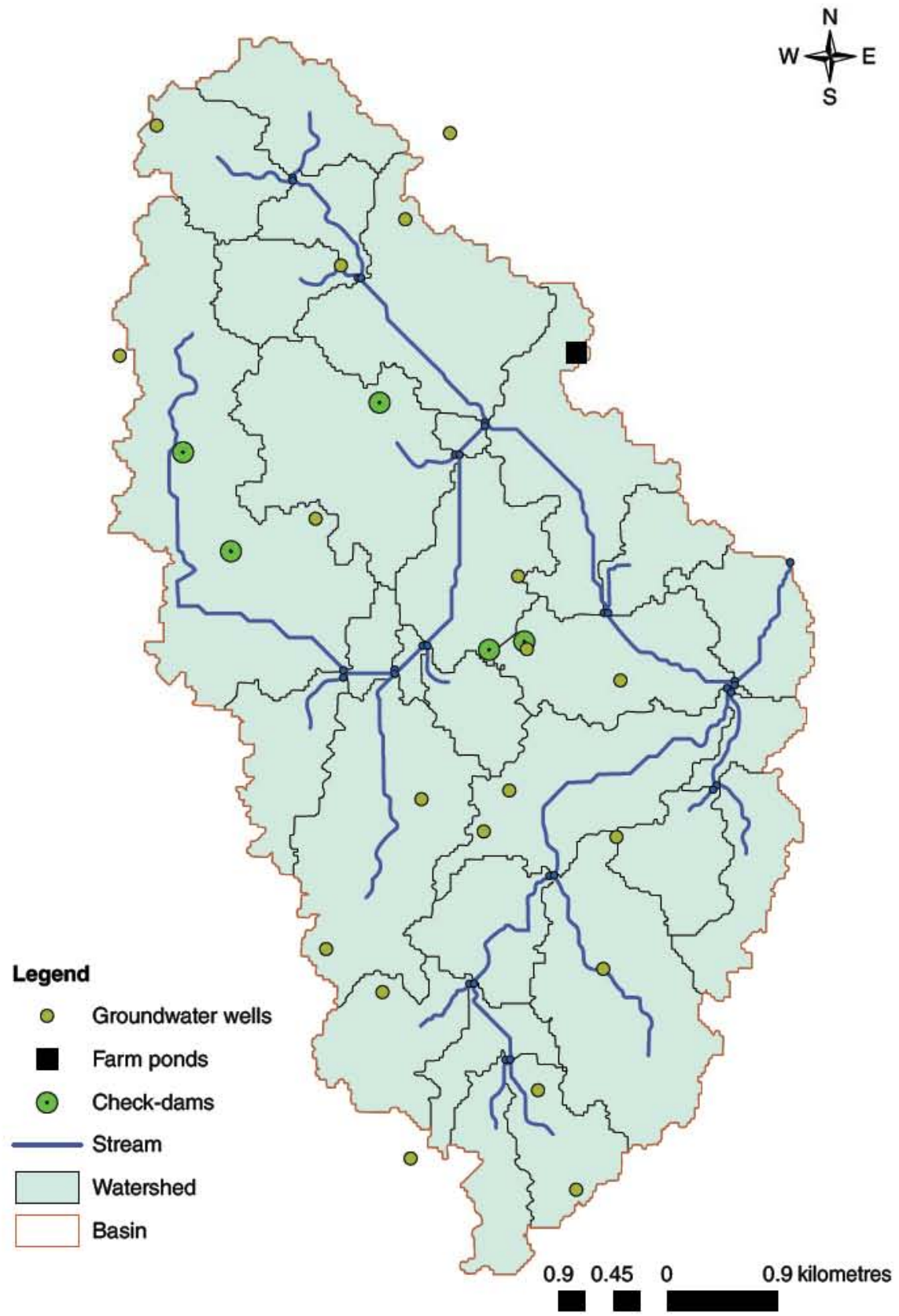

Fig. 5.5. Hydrological map of SABMiller India Project Watershed started in 2009.

total recharge made and remaining $20 \%$ was assumed to be evapotranspiration losses from the structures.

In Watershed 2009 (Fig. 5.5), treatment of the agricultural lands with different interventions, especially with water-harvesting structures was started in 2010 with a storage capacity of $3400 \mathrm{~m}^{3}$ and reached $47,700 \mathrm{~m}^{3}$ by 2014 . The increase in water table due to annual recharge by all the structures in Watershed 2009 was $17 \mathrm{~mm}$ in 2010 and then rose to $173 \mathrm{~mm}(0.17 \mathrm{~m})$ by 2014 . The average watershed area that could 
Table 5.7. Water-harvesting capacity created from 2010 to 2016 in Watershed 2009.

\begin{tabular}{|c|c|c|c|c|c|c|c|c|c|}
\hline \multirow[b]{2}{*}{ Particulars } & \multirow{2}{*}{$\begin{array}{c}\text { Geographical } \\
\text { area (ha) }\end{array}$} & \multirow{2}{*}{$\begin{array}{l}\text { Agricultural } \\
\text { land (ha) }\end{array}$} & \multicolumn{7}{|c|}{ Storage capacity created $\left(\mathrm{m}^{3}\right)$} \\
\hline & & & 2010 & 2011 & 2012 & 2013 & 2014 & 2015 & 2016 \\
\hline \multicolumn{10}{|l|}{ Village } \\
\hline Fasalvadi & 1,312 & 963 & 1,450 & 13,400 & 5,750 & 8,200 & & & \\
\hline Shivampet & 1,045 & 1,023 & 1,950 & 6,400 & 3,650 & 4,550 & 300 & & \\
\hline Venkatakistapur & 298 & 296 & & 350 & & & 1,700 & & \\
\hline Chakriyal & 658 & 633 & & & & & & & \\
\hline Total area & 3,313 & 2,915 & & & & & & & \\
\hline $\begin{array}{l}\text { Annual storage } \\
\text { capacity created }\end{array}$ & & & 3,400 & 20,150 & 9,400 & 12,750 & 2,000 & 0 & 0 \\
\hline $\begin{array}{l}\text { Cumulative } \\
\text { storage capacity } \\
\text { created }\left(\mathrm{m}^{3}\right)\end{array}$ & & & 3,400 & 23,550 & 32,950 & 45,700 & 47,700 & 47,700 & 47,700 \\
\hline
\end{tabular}

Table 5.8. Water harvesting capacity created from 2013 to 2016 in Watershed 2013-14.

\begin{tabular}{|c|c|c|c|c|c|c|}
\hline \multirow[b]{2}{*}{ Particulars } & \multirow{2}{*}{$\begin{array}{c}\text { Geographical } \\
\text { area (ha) }\end{array}$} & \multirow{2}{*}{$\begin{array}{l}\text { Agricultural } \\
\text { land (ha) }\end{array}$} & \multicolumn{4}{|c|}{ Storage capacity created $\left(\mathrm{m}^{3}\right)$} \\
\hline & & & 2013 & 2014 & 2015 & 2016 \\
\hline \multicolumn{7}{|l|}{ Village } \\
\hline Vendikole & 360 & 345 & 150 & 450 & 4,300 & \\
\hline Korpole & 1,520 & 1,468 & & 1,800 & 9,350 & 1,300 \\
\hline Sultanpur & 960 & 939 & & 6,550 & 1,900 & \\
\hline Upparigudem & 272 & 250 & & & 100 & 3,550 \\
\hline Chowtakur & 992 & 957 & & & 7,650 & \\
\hline Bommareddygudem & 244 & 221 & & & & \\
\hline Total area & 4,348 & 4,180 & & & & \\
\hline Annual storage & & & 150 & 8,800 & 23,300 & 4,850 \\
\hline
\end{tabular}

Table 5.9. Number of plants planted in the project villages during 2010-16.

\begin{tabular}{lrrrrrrrr}
\hline Type of plants & \multicolumn{1}{c}{2010} & 2011 & 2012 & 2013 & 2014 & 2015 & 2016 & Total \\
\hline Tree plantation & 12,200 & 7,100 & 1,500 & 13,160 & 16,500 & - & 2,500 & 52,960 \\
Fruit/horticulture trees & 3,200 & 2,960 & 1,200 & 2,900 & 1,200 & 1,200 & 1,400 & 14,060 \\
\hline
\end{tabular}

be sown in rabi due to recharged amount of water with chickpea crop was $5 \%$ in 2010 , and then increased to $54 \%$ of watershed area by 2016 due to water-harvesting structures in Watershed 2009 (Table 5.12).

In Watershed 2013-14 (Fig. 5.6), treatment of the agricultural lands with different interventions, especially with water harvesting structures was started in 2013 with a storage capacity of $150 \mathrm{~m}^{3}$ and reached $37,100 \mathrm{~m}^{3}$ by 2016. The increase in water table due to annual recharge by all the structures in Watershed 2013-14 was $7 \mathrm{~mm}$ in 2010 and then rose to
$102 \mathrm{~mm}(0.1 \mathrm{~m})$ by 2016 . The average watershed area that could be sown in rabi due to recharged amount of water with chickpea crop was $2 \%$ in 2013 , and then increased to $32 \%$ of watershed area by 2016 due to water harvesting structures in Watershed 2013-14 (Table 5.13).

\subsubsection{Agroforestry and tree plantation}

Considering $50 \%$ survival rate and estimates based on biomass generation, nearly 132 tons 
Table 5.10. Crop yields (t/ha) with farmers' practice (FP) and improved practice (IP) in project villages during $2010-16$.

\begin{tabular}{|c|c|c|c|c|c|c|c|c|c|c|c|}
\hline Crop treatment & $2010-11$ & 2011-12 & $2012-13$ & 2013-14 & 2014-15 & 2015-16 & $2016-17$ & Maximum & Minimum & Mean & $\begin{array}{l}\text { Increase } \\
\text { in yield }\end{array}$ \\
\hline Chickpea-FP & 0.93 & & 1.5 & & & & 1.8 & 1.80 & 0.93 & 1.41 & \\
\hline Chickpea-IP & 1.23 & & 1.9 & & & & 2.3 & 2.30 & 1.23 & 1.81 & 0.40 \\
\hline Cotton-FP & 1.6 & 1.4 & 2.4 & 2.2 & 2.4 & 2.1 & 2.2 & 2.40 & 1.40 & 2.04 & \\
\hline Cotton-IP & 1.8 & 1.6 & 2.9 & 2.6 & 2.8 & 2.6 & 2.7 & 2.90 & 1.60 & 2.43 & 0.39 \\
\hline Maize-FP & & & & & & 4.2 & 4 & 4.20 & 4.00 & 4.10 & \\
\hline Maize-IP & & & & & & 4.9 & 4.8 & 4.90 & 4.80 & 4.85 & 0.75 \\
\hline Paddy-FP & 4.8 & 5.4 & 6.1 & 5.3 & 4.3 & 2.7 & 4.2 & 6.10 & 2.70 & 4.69 & \\
\hline Paddy-IP & 5.5 & 6.1 & 7.4 & 6 & 5.2 & 3.4 & 5 & 7.40 & 3.40 & 5.51 & 0.82 \\
\hline Pigeonpea-FP & & & & & & 0.6 & 1.6 & 1.60 & 0.60 & 1.10 & \\
\hline Pigeonpea-IP & & & & & & 0.8 & 2 & 2.00 & 0.80 & 1.40 & 0.30 \\
\hline Sugarcane-FP & 146 & 108 & 101 & 86 & 92 & 65.6 & 64.3 & 146.0 & 64.30 & 94.70 & \\
\hline Sugarcane-IP & 158 & 116 & 114 & 97 & 100 & 75.2 & 73.1 & 158.0 & 73.10 & 104.76 & 10.06 \\
\hline
\end{tabular}


Table 5.11. Farmers' income (in ₹000s per ha) with farmers' practice (FP) and improved practice (IP) in project villages during $2010-16$.

\begin{tabular}{|c|c|c|c|c|c|c|c|c|c|c|c|}
\hline Crop treatment & $2010-11$ & 2011-12 & $2012-13$ & $2013-14$ & 2014-15 & $2015-16$ & $2016-17$ & Maximum & Minimum & Mean & $\begin{array}{l}\text { Increase in } \\
\text { net income }\end{array}$ \\
\hline Chickpea-FP & 21.4 & & 52.4 & & & & 87.3 & 87.3 & 21.4 & 53.7 & \\
\hline Chickpea-IP & 28.4 & & 65.4 & & & & 114.9 & 114.9 & 28.4 & 69.6 & $15.9(30)$ \\
\hline Cotton-FP & 62.0 & 43.2 & 88.2 & 101.5 & 95.4 & 87.9 & 108.2 & 108.2 & 43.2 & 83.8 & \\
\hline Cotton-IP & 72.0 & 49.6 & 106.7 & 121.7 & 111.7 & 107.1 & 133.8 & 133.8 & 49.6 & 100.4 & $16.6(20)$ \\
\hline Maize-FP & & & & & & 58.6 & 56.2 & 58.6 & 56.2 & 57.4 & \\
\hline Maize-IP & & & & & & 68.1 & 67.3 & 68.1 & 67.3 & 67.7 & $10.3(18)$ \\
\hline Paddy-FP & 43.2 & 48.5 & 95.1 & 68.5 & 47.7 & 40.9 & 65.6 & 95.1 & 40.9 & 58.5 & \\
\hline Paddy-IP & 49.3 & 55.1 & 115.4 & 78.4 & 56.9 & 50.5 & 77.1 & 115.4 & 49.3 & 69.0 & $10.5(18)$ \\
\hline Pigeonpea-FP & & & & & & 48.2 & 77.5 & 77.5 & 48.2 & 62.9 & \\
\hline Pigeonpea-IP & & & & & & 60.3 & 93.7 & 93.7 & 60.3 & 77.0 & $14.2(23)$ \\
\hline Sugarcane-FP & 306.6 & 226.8 & 261.9 & 222.4 & 239.5 & 170.5 & 190.2 & 306.6 & 170.5 & 231.1 & \\
\hline Sugarcane-IP & 332.2 & 243.6 & 295.9 & 252.2 & 260.6 & 195.5 & 216.3 & 332.2 & 195.5 & 256.6 & $25.5(11)$ \\
\hline
\end{tabular}

"Figures in parentheses are percentage values. 
Table 5.12. Benefits of water harvesting structures in Watershed 2009.

\begin{tabular}{|c|c|c|c|c|c|c|c|}
\hline Particulars & 2010 & 2011 & 2012 & 2013 & 2014 & 2015 & 2016 \\
\hline Geographical area (ha) & 2,357 & 3,313 & 3,313 & 3,313 & 3,313 & 3,313 & 3,313 \\
\hline Agricultural land (ha) & 1,986 & 2,915 & 2,915 & 2,915 & 2,915 & 2,915 & 2,915 \\
\hline Storage capacity created $\left(\mathrm{m}^{3}\right)$ & 3,400 & 20,150 & 9,400 & 12,750 & 2,000 & 0 & 0 \\
\hline Cumulative storage capacity created $\left(\mathrm{m}^{3}\right)$ & 3,400 & 23,550 & 32,950 & 45,700 & 47,700 & 47,700 & 47,700 \\
\hline Rainfall (mm) & 1,093 & 605 & 768 & 1,251 & 904 & 605 & $1,037.7$ \\
\hline Rainy year & Normal & Dry & Normal & Wet & Normal & Dry & Normal \\
\hline No. of water fillings at structures & 3 & 2 & 2 & 4 & 3 & 2 & 3 \\
\hline Total quantity of recharge $\left(\mathrm{m}^{3}\right)$ & 10,200 & 47,100 & 65,900 & 182,800 & 143,100 & 95,400 & 143,100 \\
\hline Total quantity of recharge $(\mathrm{mm})$ & 0.43 & 1.42 & 1.99 & 5.52 & 4.32 & 2.88 & 4.32 \\
\hline Effective recharge $(\mathrm{mm})$ (reducing $\mathrm{Et}^{\mathrm{a}} 20 \%$ ) & 0.35 & 1.14 & 1.59 & 4.41 & 3.46 & 2.30 & 3.46 \\
\hline Increase in water table (specific yield 0.02$)(\mathrm{mm})$ & 17.31 & 56.87 & 79.57 & 220.71 & 172.77 & 115.18 & 172.77 \\
\hline Increase in water table $(\mathrm{m})$ & 0.02 & 0.06 & 0.08 & 0.22 & 0.17 & 0.12 & 0.17 \\
\hline Effective groundwater available for rabi $(70 \%)(\mathrm{mm})$ & 12.12 & 39.81 & 55.70 & 154.49 & 120.94 & 80.63 & 120.94 \\
\hline Post-monsoonal soil moisture $(\mathrm{mm})$ & 25 & 25 & 25 & 25 & 25 & 25 & 25 \\
\hline Chickpea water requirement (mm) & 250 & 250 & 250 & 250 & 250 & 250 & 250 \\
\hline Extra water requirement for chickpea in rabi (mm) & 225 & 225 & 225 & 225 & 225 & 225 & 225 \\
\hline Extra area could be sown with chickpea (\%) & 5.39 & 17.69 & 24.75 & 68.66 & 53.75 & 35.83 & 53.75 \\
\hline
\end{tabular}

${ }^{\mathrm{a}} \mathrm{E} \mathrm{t}=$ evapotranspiration 


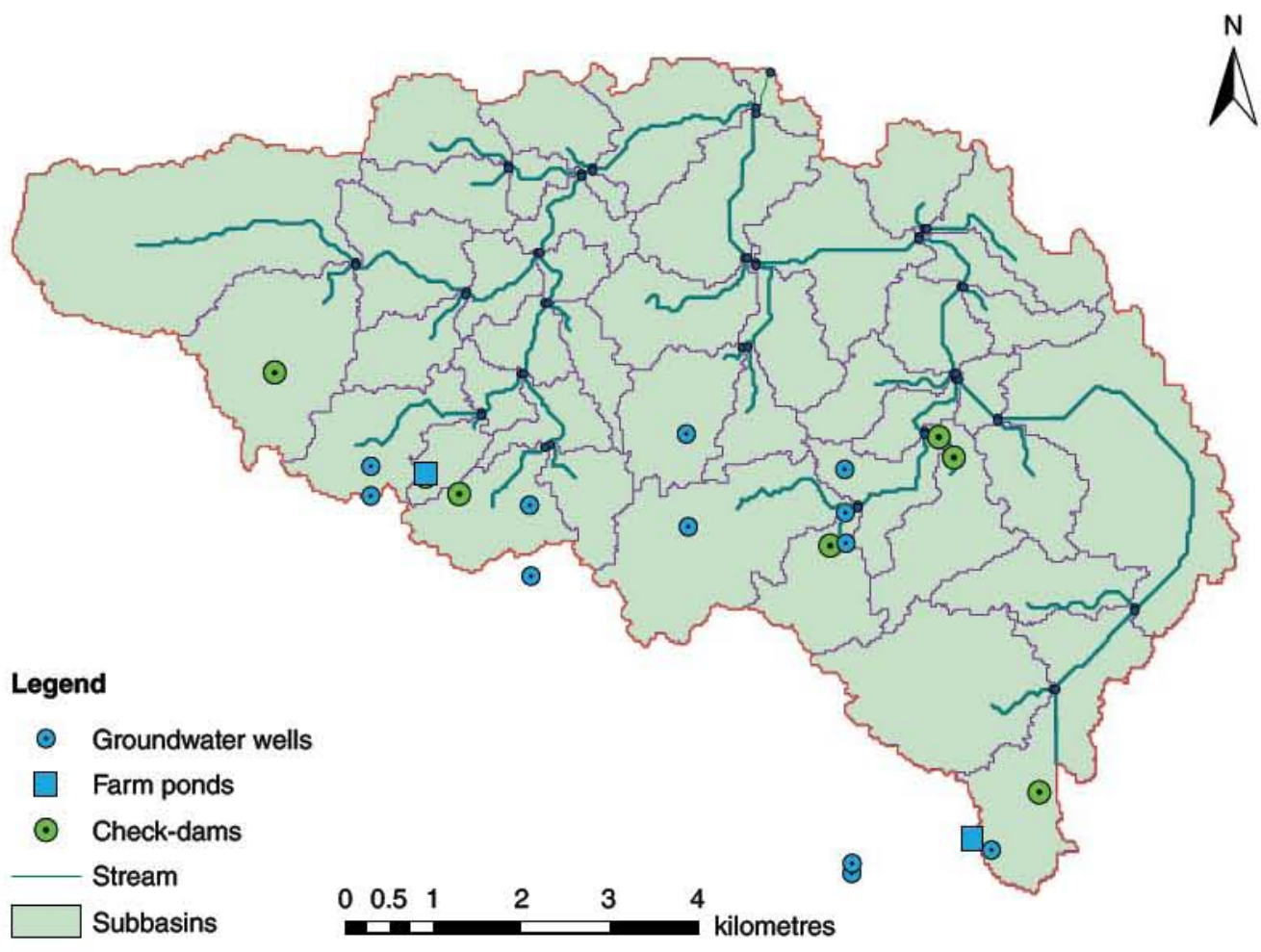

Fig. 5.6. Hydrological map of SABMiller India Project Watershed started in 2013-14.

Table 5.13. Benefits of water harvesting structures in Watershed 2013-14.

\begin{tabular}{lcccc}
\hline Particulars & 2013 & 2014 & 2015 & 2016 \\
\hline Geographical area (ha) & 360 & 2,840 & 4,348 & 4,348 \\
Agricultural land (ha) & 345 & 2,752 & 4,180 & 4,180 \\
Storage capacity created $\left(\mathrm{m}^{3}\right)$ & 150 & 8,800 & 23,300 & 4,850 \\
Cumulative storage capacity created $\left(\mathrm{m}^{3}\right)$ & 150 & 8,950 & 32,250 & 37,100 \\
Rainfall $(\mathrm{mm})$ & 1,251 & 904 & 605 & 1,038 \\
Rainy year & Wet & Normal & Dry & Normal \\
No. of water fillings at structures & 4 & 3 & 2 & 3 \\
Total quantity of recharge $\left(\mathrm{m}^{3}\right)$ & 600 & 26,850 & 64,500 & 111,300 \\
Total quantity of recharge $(\mathrm{mm})$ & 0.17 & 0.95 & 1.48 & 2.56 \\
Effective recharge $(\mathrm{mm})$ (reducing Eta $20 \%)$ & 0.13 & 0.76 & 1.19 & 2.05 \\
Increase in water table $($ specific yield 0.02$)(\mathrm{mm})$ & 6.67 & 37.82 & 59.34 & 102.39 \\
Increase in water table $(\mathrm{m})$ & 0.01 & 0.04 & 0.06 & 0.10 \\
Effective groundwater available for rabi $(70 \%)(\mathrm{mm})$ & 4.67 & 26.47 & 41.54 & 71.67 \\
Post-monsoonal soil moisture $(\mathrm{mm})$ & 25 & 25 & 25 & 25 \\
Chickpea water requirement $(\mathrm{mm})$ & 250 & 250 & 250 & 250 \\
Extra water requirement for chickpea in rabi $(\mathrm{mm})$ & 225 & 225 & 225 & 225 \\
Extra area could be sown with chickpea $(\%)$ & 2.07 & 11.77 & 18.46 & 31.86 \\
\hline
\end{tabular}

${ }^{a} \mathrm{Et}=$ evapotranspiration 
of carbon was sequestered during the project period (Table 5.14). As most of the plants are about 6 years old, biomass accumulation will accelerate in subsequent years with increasing tree age. Due to various agricultural water management interventions, soil loss has been reduced

Table 5.14. Impact of agricultural water management interventions on various ecosystem services.

\begin{tabular}{lc}
\hline Parameter & Amount \\
\hline Rainfall (mm) & 895 \\
Reduced soil erosion ( $t / \mathrm{ha})$ & From 10 to 3 \\
No. of trees planted & 52,960 \\
$\begin{array}{l}\text { No. of trees established } \\
\quad(50 \% \text { survival rate) }\end{array}$ & 26,480 \\
$\begin{array}{l}\text { Average biomass accumulated } \\
\quad \text { (considering 10 kg wood/tree) }\end{array}$ & 265 \\
$\quad$ (tons) & \\
Carbon sequestered (tons) & 132 \\
\hline
\end{tabular}

from $10 \mathrm{t} / \mathrm{ha}$ to $3 \mathrm{t} / \mathrm{ha}$, thus significantly contributing to reduction in land degradation and increase in crop productivity.

\subsubsection{Livestock-based activities}

As livestock is the integral part of the rural community, special emphasis was laid on livestockbased activities and increase in milk yield. Breed improvement of cattle was undertaken on a large scale in pilot villages (Fig. 5.7). Nearly 2421 animals were inseminated artificially and of those 1151 confirmed pregnancy. This has increased milk yield by $2-31 /$ day/animal more than the local breed. Also, spent malt (a byproduct of the brewing industry, rich in carbohydrate, protein and other minerals) was promoted for use as animal feed. Four women's self-help groups (SHGs) were engaged in procuring, transporting

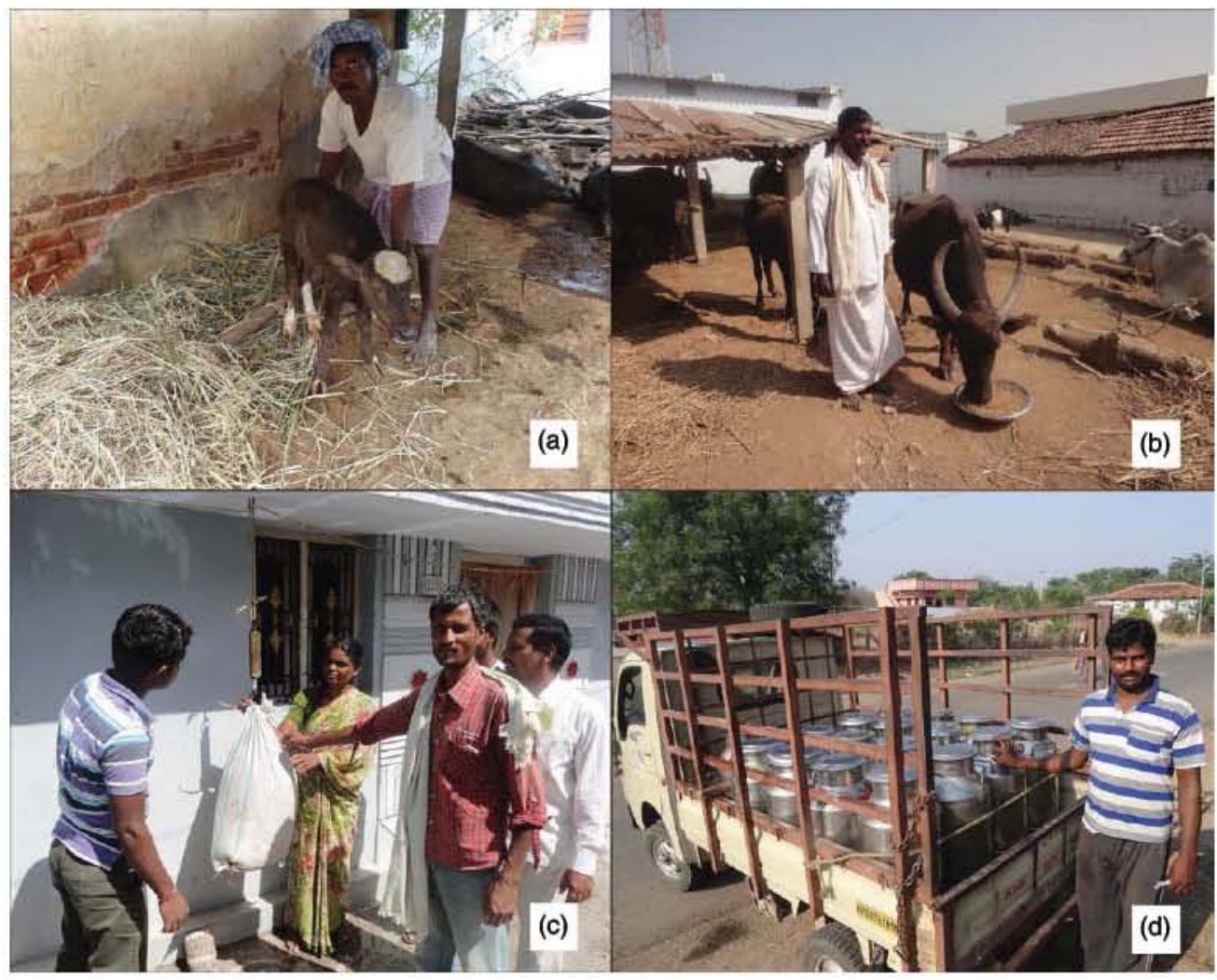

Fig. 5.7. Cattle improvement in Fasalvadi village: (a) first generation crossbreed; (b) spent malt used as feed for animals; (c) sale of spent malt to farmers; (d) milk collection in the village. 
and distributing the spent malt as a business model in the villages and households and women's SHGs are benefiting from this intervention (Table 5.15).

\subsubsection{Income-generating activities by women}

Various income-generating activities such as vermicomposting (11 units), nursery raising and other microenterprises helped farmers to earn additional income. Kitchen gardens have been promoted to address nutritional issues, especially for women and children.

\section{Nursery raising}

The project provided opportunities to women's SHGs to strengthen their livelihoods. Women's SHG Manjeera in Venkatakistapur village has undertaken nursery raising and grown about 12,000 saplings of teak, Pongamia, rain trees, Gliricidia, tamarind and Pithecellobium dulce to plant them in the project villages. Besides attending to their regular jobs, the SHG members supplied 10,056 saplings at ₹6 per sapling and earned ₹60,336 as additional income.
Table 5.15. Increase in milk yield and income in Fasalvadi village with spent malt as animal feed during 2011 to $2016 .^{\mathrm{a}}$

\begin{tabular}{lr}
\hline $\begin{array}{l}\text { Particulars } \\
\text { No. of beneficiary households using } \\
\text { spent malt }\end{array}$ & $\begin{array}{r}\text { Quantity/ } \\
\text { Amount }\end{array}$ \\
$\begin{array}{l}\text { No. of cattle (feeding) } \\
\text { Average use of spent malt in the village } \\
\text { (kg/day) }\end{array}$ & 1,440 \\
$\begin{array}{l}\text { Milk production in the village (I/day) } \\
\begin{array}{l}\text { Increase in milk production by feeding } \\
\text { spent malt (l/animal/day) }\end{array}\end{array}$ \\
$\begin{array}{l}\text { Increase in gross income due to spent } \\
\text { malt (₹/day) }\end{array}$ & 1,570 \\
$\begin{array}{l}\text { Increase in net income due to spent } \\
\text { malt (₹/day) }\end{array}$ & 17,800 \\
$\begin{array}{l}\text { Increase in average net income due to } \\
\text { spent malt (₹/family/month) }\end{array}$ & 6,640 \\
$\begin{array}{l}\text { Increase in average net income due to } \\
\text { artificial insemination (₹/family/ } \\
\text { month) }\end{array}$ & 3,375 \\
$\begin{array}{l}\text { Total increase in income due to spent } \\
\text { malt and artificial insemination } \\
\text { (₹/family/month) }\end{array}$ & 10,015 \\
$\begin{array}{l}\text { Spent malt sold by the SHG (tons) } \\
\text { Net profit to SHG (₹) }\end{array}$ & 2,610 \\
\hline
\end{tabular}

aIntervention by women's self-help group (SHG) Priyadarshini.

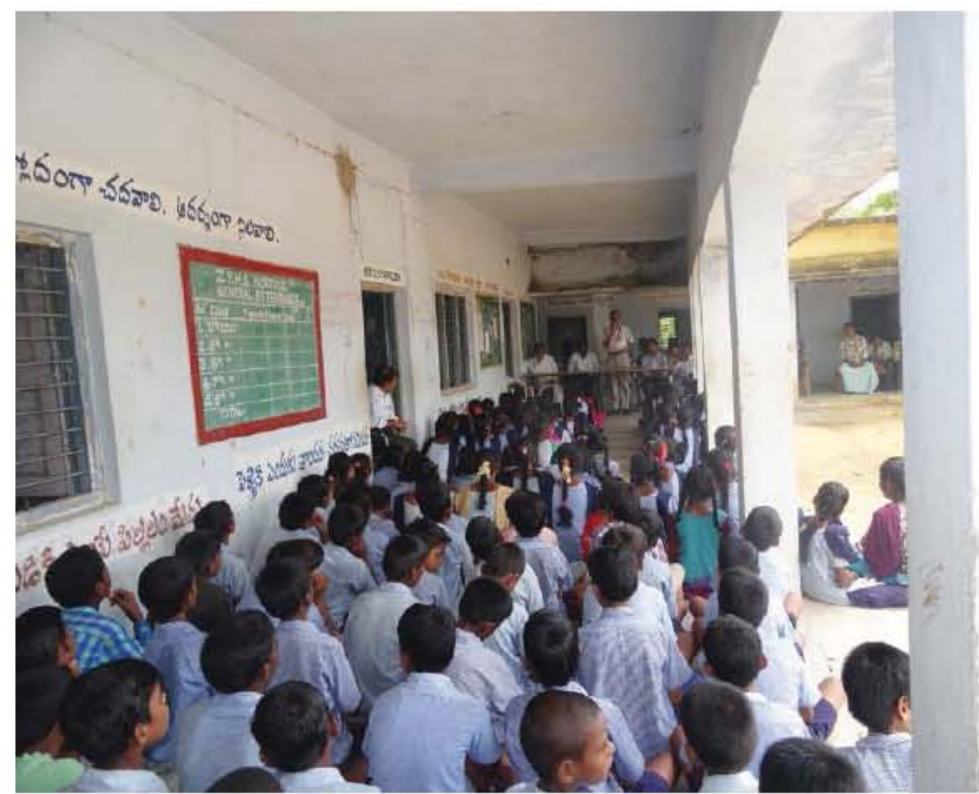

Fig. 5.8. Awareness programme for school children on balanced nutrition in Korpole government school. 


\section{Nutri-kitchen gardens}

In India, the problem of malnutrition in women and children is a serious issue, as $42 \%$ of children and about $34 \%$ of women in the country are malnourished. At the same time, many women and children are becoming disconnected from nature and there is an urgent need to increase awareness about balanced nutrition as well as environmental protection. To address the issue of malnutrition in children and women, there is a need to promote sustainable kitchen gardens for effective utilization of available natural resources like water and land by using organic farming methods, as well as to improve diet by the inclusion of fresh and safe nutritious vegetables produced in kitchen gardens. By taking up this activity, school children will gain hands-on experience in some areas of the school curriculum (e.g. science, agriculture, environmental science and home economics) (Fig. 5.8).

Interested women's SHG members and school children were identified to undertake this activity and registered for seed kits to initiate this activity in their backyards. Each member was provided with seed kits of nine vegetables (tomato, brinjal, okra, cluster bean, bottle gourd, bitter gourd, ridge gourd, spinach and amaranth) of their choice to grow in their kitchen gardens (Fig. 5.9). About 168 kitchen gardens were promoted during the rainy season of 2015, and $6300 \mathrm{~kg}$ vegetables were produced. During the rainy season of 2016,178 kitchen gardens were promoted and $7480 \mathrm{~kg}$ vegetables were produced and used for consumption in the project villages (Table 5.16). This activity has helped in reducing the expenditure on vegetables.

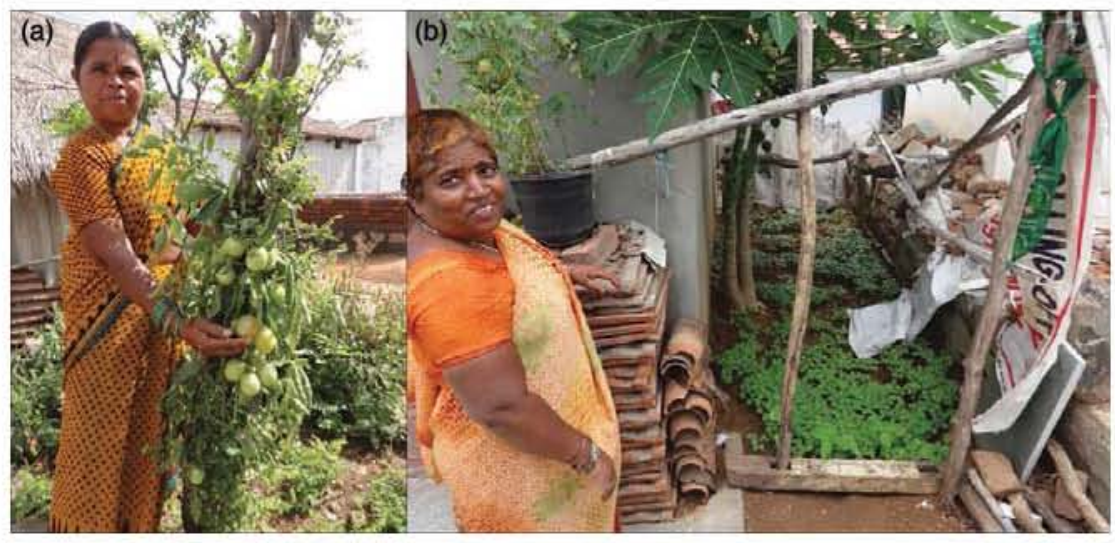

Fig. 5.9. Kitchen garden grown by women in (a) Chowtakur and (b) Sultanpur villages.

Table 5.16. Progress of kitchen gardens in the project villages.

\begin{tabular}{|c|c|c|c|c|}
\hline \multirow[b]{2}{*}{ Village } & \multicolumn{2}{|c|}{2015} & \multicolumn{2}{|c|}{2016} \\
\hline & $\begin{array}{l}\text { No. of units } \\
\text { promoted }\end{array}$ & $\begin{array}{c}\text { Vegetable } \\
\text { production }(\mathrm{kg})\end{array}$ & $\begin{array}{l}\text { No. of units } \\
\text { promoted }\end{array}$ & $\begin{array}{c}\text { Vegetable } \\
\text { production }(\mathrm{kg})\end{array}$ \\
\hline Fasalvadi & 10 & 490 & 20 & 830 \\
\hline Shivampet & 80 & 2400 & 15 & 590 \\
\hline Chakriyal & - & - & 15 & 620 \\
\hline Venkatakistapur & 10 & 410 & 15 & 670 \\
\hline Korpole & 13 & 590 & 20 & 730 \\
\hline Sultanpur & 10 & 430 & 18 & 710 \\
\hline Chowtakur & 18 & 720 & 25 & 1140 \\
\hline Vendikol & - & - & 20 & 890 \\
\hline Bommareddygudem & 13 & 590 & 15 & 640 \\
\hline Upparigudem & 14 & 670 & 15 & 660 \\
\hline Total & 168 & 6300 & 178 & 7480 \\
\hline
\end{tabular}




\section{Acknowledgements}

The authors would like to thank SABMiller India, now $A B$ InBev, for the finance and spent malt supply to the farmers; thanks to Government of
Telangana officers for their constant support to the farmers and the project; and thanks to all the farmers in the SABMiller Project villages for the participation and contribution in the success of the project.

\section{References}

Government of India (2011) Common Guidelines for Watershed Development Projects - 2008 (Revised Edition - 2011) New Delhi: National Rainfed Area Authority, Planning Commission. Available at: http:// dolr.nic.in/dolr/downloads/pdfs/Common\%20Guidelines\%20for\%20WDP\%202008\%20Revised\%20 Edition\%202011.pdf (accessed 12 April 2018).

Sahrawat, K.L., Rego, T.J., Wani, S.P. and Pardhasaradhi, G. (2008) Stretching soil sampling to watershed: evaluation of soil-test parameters in a semi-arid tropical watershed. Communications in Soil Science and Plant Analysis 39(19-20), 2950-2960.

Srinivasa Rao, C., Wani, S.P., Chander, G. and Sahrawat, K.L. (2014) Balanced nutrient management for crop intensification and livelihood improvement: a case study from watershed in Andhra Pradesh, India. Communications in Soil Science and Plant Analysis 45(19), 2515-2528. DOI: 10.1080/ 00103624.2014 .912298$.

Thirtle, C., Beyers, L., McKenzie-Hill, V., Irz, X., Wiggins, S. and Piesse, J. (2002) The Impacts of Changes in Agricultural Productivity on the Incidence of Poverty in Developing Countries. DFID Report No. 7946. Department for International Development, London.

World Bank (2005) Agricultural Growth for the Poor: An Agenda for Development. International Bank for Reconstruction and Development/The World Bank, Washington, DC. 